\title{
Music, Media and Culture One Generation after Yugoslavia: Do we Still Need 'Nostalgia'?
}

\author{
Catherine Baker \\ University of Hull
}

\section{Introduction}

Almost 30 years after the Yugoslav wars began, popular culture travels across postYugoslav borders much more vibrantly than outside observers often expect. The continuities, or what seem like continuities, between Yugoslavia's common cultural space and a post-Yugoslav cultural space which even transcends former front lines frequently seem to be signs of 'nostalgia', a complicated set of longings for the Yugoslav past which sociologists of culture have been trying to explain since the 1990s. And yet, apparent continuities on the surface of the so-called 'Yugosphere' may be misleading. ${ }^{1}$ While they depend on legacies, networks, social identities and tastes formed during Yugoslavia or earlier, they have actually been reconstructed in wartime and post-war political contexts, and are always being contested and renegotiated. Examining postYugoslav media and culture from today's perspective, however, suggests two striking things. One is that how far a text, performer or genre can be 'marked' or 'unmarked' as politicized or 'nostalgic' is socially constructed, not predetermined; the other is that today - unlike the 1990s - these apparent continuities are often produced without evoking any remembering of Yugoslavia at all. Meanwhile, enough time has passed since the wars that the wartime past itself can exhibit more political strength than nostalgia for Yugoslavia has ever held. While some scholars have begun questioning whether 'nostalgia' is still even useful in understanding post-Yugoslav media and culture, ${ }^{2}$ this juxtaposition shows that 'nostalgia' is still a relevant concept for postYugoslav cultural politics today - as long as it points to the active experiences and emotions of remembering, not just to everything which happens within the borders of where Yugoslavia used to be.

1 See Tim Judah, 'Yugoslavia is Dead, Long Live the Yugosphere', LSEE Research on South-Eastern Europe Working Papers 1 (London, 2009). Available at: http://eprints.lse.ac.uk/48041/1/_Libfile_ repository_Content_LSEE_Papers\%20on\%20South\%20Eastern\%20Europe_Yugoslavia\%20is\%20 Dead(author).pdf (accessed 9 November 2017).

2 Dalibor Mišina, 'Beyond Nostalgia: "Extrospective Introspections" of the Post-Yugoslav Memory of Socialism' (2016) 1 Canadian-American Slavic Studies 332-54. 
Ever since commentators began noticing apparent signs of 'nostalgia' for Yugoslavia, while the 1990s wars were still at their height, many 'continuities' they noticed involved popular music. The underground popularity of Serbian as well as Bosnian 'newlycomposed folk songs' or 'narodnjaci' in Croatia during the 1991-95 'Homeland War' contradicted the clear cultural boundaries between Croats and Serbs which President Franjo Tuđman's interpretation of the Croatian independence project had needed to establish, arguably at the expense of much personal memory and ambiguity. ${ }^{3}$ Croatian journalists were surprised to see some of the same troops who were fighting the Yugoslav People's Army (JNA) and the paramilitaries who had declared a 'Republic of Serb Krajina' (RSK) listening to 'eastern'-sounding 'narodnjaci' in Croatian nightclubs or tuning into Serbian radio stations to listen to Serbian music as well as monitor 'enemy' news. ${ }^{4}$ The root of their surprise was the idea that members of a nation involved in ethnopolitical conflict would willingly admit music or other cultural forms from the 'aggressor' nation into their own cultural worlds. Today, ethnicized processes of separation and distancing have had two more decades to harden - yet the region's sociocultural connectedness is stronger than during the 1990s. And observers are often still surprised.

Moreover, post-Yugoslav sociocultural connectivities have strengthened even though more and more viewers and listeners and fans do not remember Yugoslavia themselves. By the time Judah popularized the 'Yugosphere' term to describe everyday patterns of post-Yugoslav cultural exchange, the region (and its diasporas) contained a generation with no lived experience of a country called 'Yugoslavia' - or of the everyday popular culture which Tito's Yugoslavia deliberately cultivated for Yugoslavs from different ethnic groups to enjoy together. The proportion of people in any postYugoslav country who remember Yugoslavia through their participation in 'Yugoslav' everyday life, rather than through media representation and intergenerational 'postmemory', will only decrease. ${ }^{5}$ Private media companies often address the whole Yugoslav region, or at least the area where Bosnian, Croatian, Montenegrin and Serbian are mutually understood, even when aiming at youth audiences: indeed, satellite and digital media (which were less constrained by state telecommunications infrastructure and national media distribution systems, i.e. the networks which fragmented when Yugoslavia broke up) have created ever more possibilities for ongoing everyday cultural exchange. If sociocultural 'nostalgia' for Yugoslavia is still a talking point, it must still be surprising. Yet is it such a surprise? Does cultural nostalgia have any political currency? Is it even nostalgia at all? Is nostalgia for the Yugoslav past the only significant nostalgia in the region's cultural politics? While the well-rehearsed framework of 'Yugonostalgia' may offer few fresh insights into understanding how far today's sociocultural connectivities are 'continuities' from Yugoslavia, appreciating the politics of emotion behind 'nostalgia' can.

3 See Alex J Bellamy, The Formation of Croatian National Identity: A Centuries-old Dream? (Manchester, 2003); Dubravka Ugrešić, The Culture of Lies: Anti-Political Essays (London, 1998).

4 Ines Sabalić, "Washingtonski sporazumi dramatično su izmijenili hrvatsku estradnu scenu: u Zagrebu je otvoreno petnaest lokala s novokomponiranom glazbom!" Globus, 31 March 1995.

5 Dijana Jelača,'Youth after Yugoslavia: Subcultures and Phantom Pain' (2014) Studies in East European Cinema v/2 139-54 at 139. 


\section{Post-socialist 'nostalgia' and the meanings of Yugoslavia}

Throughout post-socialist Europe, not just the Yugoslav region, post-socialist 'nostalgia' for everyday personal and cultural memories of Communist regimes has fascinated cultural commentators. ${ }^{6}$ Scholars and critics have wondered particularly at Ostalgie (nostalgia for aspects of life under the German Democratic Republic (GDR)) in reunified Germany, and the 'nostalgia' for a lost multinational federation as well as a state socialist regime that drives many forms of post-Soviet, as well as post-Yugoslav, nostalgia. Indeed, the fact that the USSR and Yugoslavia both fragmented along state socialist internal boundaries has continued to invite comparisons between their aftermaths, even though in the 1990s, immediate ethnopolitical conflict had less impact on post-Soviet nostalgia outside the Caucasus. ${ }^{7}$ Ethnicized historical memories of national victimhood (such as Stalin's subjection of Ukrainians to a forced famine which Ukrainian national memory considers genocidal, and his wartime deportation of border minorities such as the Crimean Tatars) nevertheless made the Soviet past ethnopolitically contentious even when republics had separated peacefully. Moreover, Russia's annexation of Crimea in 2014 and its support for RSK-like separatist entities in eastern Ukraine has reconfigured the politics of Russian/Ukrainian nostalgia and cultural exchange into a situation closer to Croatian-Serbian cultural relations in the 1990s. ${ }^{8}$

Commentators on the politics - and political economy - of post-Yugoslav 'nostalgia' have emphasized that the simple term 'nostalgia' conceals many possible reference points and emotions. 'Nostalgia' could involve expressions and symbols of the fact that many people, even in countries which had fought for independence against the JNA, wondered retrospectively if their lives would have been more prosperous and fulfilling if Yugoslavia had stayed together or if there had not been a war. And it could involve other aspects: regret that there had been more inter-ethnic coexistence and geographical mobility in Yugoslavia than during or after the wars, when national publics came under growing pressure to identify with narrowly defined notions of ethnicity and culture which might not match the social reality they had experienced; young people's desire to provoke their elders, which could explain why a Croatian teenager who did not remember Tito would wear a Tito t-shirt or sing along with a punk version of a Partisan song, but should not be taken as the only reason why; the acts of digital archiving and

6 See Svetlana Boym, The Future of Nostalgia (New York, 2001); Maria Todorova and Zsuzsa Gille (eds), Post-Communist Nostalgia (New York, 2010).

7 See Rogers Brubaker, Nationalism Reframed: Nationhood and the National Question in the New Europe (Cambridge, 1996); Veljko Vujačić, Nationalism, Myth and the State in Russia and Serbia: Russian and East European Government Politics and Policy (Cambridge, 2015).

8 Eg, Ukrainian security services have banned more than 140 Russian entertainers who have visited Crimea from entering Ukraine, constraining the everyday presence current Russian popular music had had in Ukraine until 2014: 'Ukraine may ban Russian entrant from Eurovision over Crimea visit', $R F E / R L, 14$ March 2017. Available at: www.rferl.org/a/ukraine-may-ban-russian-entrantsamoylova-eurovision-contest-over-crimea-visit/28368002.html (accessed 9 November 2017). In 2017, when Kiev hosted the Eurovision Song Contest (following Ukraine's win in 2016 with a song commemorating the Tatars' deportation and, implicitly, Russia's annexation of Crimea), this extended to Russia’s Eurovision representative, Yulia Samoilova.

9 See Vjekoslav Perica and Mitja Velikonja, Nebeska Jugoslavija: interakcije političkih mitologija i pop-kulture (Belgrade, 2012). 
curating with which internet users have assembled 'micro-archives' of the Yugoslav past since the 1990s; ${ }^{10}$ and ways of expressing as-yet-unrealized 'vision[s] for the future' by ostensibly representing the past. ${ }^{11}$

In the mid-2000s, the media scholar Zala Volčič discerned three aspects of nostalgia for Yugoslavia as follows: ${ }^{12}$ a political or 'revisionist' nostalgia which did look to the unified South Slav state (or, she might have added, state socialism) as a more desirable model than its individual ethnonational (and increasingly neoliberalized) successors; an 'aesthetic' nostalgia which called for 'the preservation of an authentic Yugoslav past'; and a commercialized 'escapist' or 'utopian' nostalgia, with largely decontextualized visual, audiovisual, sonic and material signifiers, which she saw as increasingly on the rise - emblematically when reunion concerts by Bijelo Dugme, the 1970s-80s Sarajevo rock band who had themselves experimented with an alternative pluralistic, emotional and 'trans-ethnic' Yugoslavism, ${ }^{13}$ were sponsored by the very symbol of globalized US cultural hegemony, Coca-Cola. Volčič was writing just before the post-Yugoslav 'New Left' would seek to reaffirm the radical potential behind Yugoslav ideas of economic management and sociality, including the mobilization of Partisan and Communist women, to open social dialogues about alternatives to neoliberalism after the global financial crisis hit south-east Europe in $2007-08 .{ }^{14}$ The contrast between the visions of the future available even during late state socialist Yugoslavia's 'crisis' years, and futures which appear far more limited from today's positions of stagnation and 'stuckness' when, often, two decades later nothing perceptible seems to have changed - blends complex emotions about the present, the future and the past.

Yet 'Yugonostalgia' first came to scholars' attention as more than just a cultural phenomenon. In early 1990s Croatia, 'Yugonostalgia' was also a political accusation used to tighten the limits of what could be said in the public sphere, with serious professional consequences for cultural workers who depended on patronage from state media and official cultural institutions. 'Yugonostalgia' then, in effect, meant any public commentary which dissented from the new Croatian intellectual establishment's ethnicized project of cultural and linguistic separation from Yugoslavia. ${ }^{15}$ Allegations of 'Yugonostalgia' brought about public hounding and death threats on writers which intimidated women, in particular, from criticizing the new regime and its patriarchal, clericalist ideology - a form of pre-emptive silencing with which feminist and marginalized writers confronting white supremacist and anti-feminist digital harassment

${ }_{10}$ Martin Pogačar, Media Archaeologies, Micro-Archives and Storytelling: Re-Presencing the Past (London, 2016).

11 Monika Palmberger, How Generations Remember: Conflicting Histories and Shared Memories in Post-War Bosnia and Herzegovina (London, 2016), p. 14.

12 Zala Volčič, '"Yugo-nostalgia: cultural memory and media in the former Yugoslavia' (2007) Critical Studies in Media Communication xxiv/1 21-38 at 27.

13 Dalibor Mišina, "'Spit and Sing, My Yugoslavia': New Partisans, Social Critique and Bosnian Poetics of the Patriotic' (2010) Nationalities Papers xxxviii/2 265-89 at 271.

14 See Srećko Horvat and Igor Štiks (eds), Welcome to the Desert of Post-Socialism: Radical Politics after Yugoslavia (London, 2015); Ana Hofman, Novi život partizanskih pesama (Belgrade, 2016).

15 This separation included sweeping changes to language policy that distanced Croatian further from Serbian, removing books in Serbian language or Cyrillic script from public libraries, and dropping Serbian or 'eastern'-sounding popular music from radio archives. 
are all too familiar today, even though the policing of their political speech has been crowd sourced not state-driven. ${ }^{16}$ Against this background, it is not hard to understand why nostalgic regard for Yugoslavia and its everyday culture should often have been interpreted as political resistance. And yet - even as Tuđman's ideology continues to structure hegemonic public discourse in Croatia almost two decades after his death ${ }^{17}$ is nostalgia always a political expression, in every post-Yugoslav context? Indeed, is every reverberation of the Yugoslav cultural past, and every common cultural space reproduced within former Yugoslavia's borders, even nostalgia at all?

The Yugoslav successor societies, moreover, each re-mediated the memory of Yugoslavia differently. Tuđman's Croatia rejected it most intensely. Slovenia's ruling liberals immediately distanced Slovenia from Yugoslavia politically, and applied citizenship laws which 'erased' more than 18,000 residents born in other Yugoslav republics (predominantly Bosnians, Albanians and Roma) from the residency register. ${ }^{18}$ Culturally, meanwhile, some young Slovenes in the 2000s took nostalgia to practically parodic levels with their enjoyment of 'Balkan parties' and consumption of Partisan kitsch. Popular culture from the Yugoslav region acquired a curious not-quite-foreign or 'ex-home' status in Slovenia, ${ }^{19}$ and the country became a semi-neutral venue for Croatian and Serbian rock bands and folk stars to perform for fans from both countries (if they could afford to travel). In Bosnia-Herzegovina (BiH), the Yugoslav Partisan tradition was reappropriated to stand for a multi-ethnic vision of citizenship and a linked socioeconomic critique of privatization by people seeking a 'civic' or multiethnic identity for $\mathrm{BiH}$. The 1992-95 war hollowed out any political platform for this 'civic' vision, while the consociational Dayton Peace Agreement enshrined the country's three largest ethnopolitical identities (Bosniak, Croat and Serb) in constitutional politics to the exclusion of all others. Macedonia, which seceded peacefully in September 1991, had arguably the fewest reasons to resent the memory of Yugoslavia, and mid-2000s Skopje boasted a minor cottage industry of Tito mementoes. ${ }^{20}$ The country's international designation as 'the Former Yugoslav Republic of Macedonia' until 2019 was not, however, a longing expression of geopolitical nostalgia, but a condition imposed by a Greek state which feared the new country could make irredentist claims to Macedonia in northern Greece.

'Yugoslavia' had yet more meanings in Serbia and Montenegro. Miloševićs regime had departed from most understandings of Yugoslavism - certainly those held by Yugoslavia's non-Serb citizens, or the Serbian democratic opposition - while retaining the name. Milošević had played the single largest role in undermining the Yugoslavia which had institutionalized Albanians' cultural and linguistic rights in Kosovo (without

\footnotetext{
16 Stine Eckert, 'Fighting for Recognition: Online Abuse of Women Bloggers in Germany, Switzerland, the United Kingdom, and the United States' (2018) New Media and Society xx/4 1282-302.

17 See Dejan Jović, Rat i mit: politika identiteta u suvremenoj Hrvatskoj (Zagreb, 2017).

18 Jelka Zorn, 'A case for Slovene Nationalism: Initial Citizenship Rules and the Erasure' (2009) Nations and Nationalism xv/2 280-98, 281.

19 Mitja Velikonja, “Ex-home”: "Balkan culture” in Slovenia after 1991' in Barbara Törnquist-Plewa and Sanimir Resić (eds), The Balkans in Focus: Cultural Boundaries in Europe (Lund, 2002).

20 Volčič, 'Yugo-nostalgia', pp 29-30.
} 
granting them equal constitutional status to South Slav peoples) and strengthened the ethnonational consciousness of Bosnian Muslims, Montenegrins and Macedonians; and he had broken from a Yugoslavia where 'worker' had once been a dignified social identity, by persuading his Serb addressees to think of themselves as Serbs not workers first (thus eroding their solidarity with other republics' disadvantaged workers, and weakening the audience for trans-republican political appeals). He had played on historical mythology of Serbs' persecution under the Ottoman Empire, and the genocide Serbs suffered in 1941-45 under the Independent State of Croatia (NDH), in persuading Serbs that Bosniaks, Albanians and Croats were historic enemies and present threats. Nevertheless, Milošević still needed to be able to claim his state had inherited Yugoslavia's sovereignty: Serbia and Montenegro thus took the name 'the Federal Republic of Yugoslavia' in April 1992, even as forces under Miloševićs control were committing atrocities in $\mathrm{BiH}$ and destroying yet more of what Yugoslavia had meant. It was officially still the Army of Yugoslavia (VJ), not Serbia, which Milošević deployed against the Kosovo Liberation Army (KLA) during the Kosovo War. It is little wonder, in view of Albanians' history in all three Yugoslavias, that Kosovo consistently registered even less political nostalgia than Croatia in sociological surveys, ${ }^{21}$ and that Kosovo's Albanian-language cultural scene belonged to a transnational 'Albanosphere' (which also extended into Macedonia) not the 'Yugosphere' structured around the languages formerly known as Serbo-Croatian.

Even in the 1990s, informal economies and alternative radio stations sustained cross-border musical connections for listeners who sought them out. The wars' denormalization of cultural exchange across the most politicized ex-Yugoslav borders, and the emotional associations with 'the aggressor' that people's wartime experiences might make them project on to popular culture from the 'wrong' sides of symbolic cultural boundaries, nevertheless made it both contested and noteworthy when crossborder performances and legitimate music releases across the most 'problematic' borders (Croatia-Serbia and BiH-Serbia) started to resume. ${ }^{22}$ Visa and customs regulations meant that states could more effectively restrict border-crossings by musicians' bodies and equipment than their sounds, so that live performance was nearly always the most contentious issue during the partial restitching of the 'Yugosphere' in 1998-2006. Today, even though direct memory of Yugoslav everyday life is far more distant, post-Yugoslav societies still have more shared cultural connections among themselves than with other adjacent states, and passing references to 'neighbouring states' invariably connote the other post-Yugoslav republics, not a country's actual geographical neighbours. This is not only the case for people who did experience Yugoslavia themselves, but also in youth culture, where broadcasters and music promoters organizing talent shows and tours are often addressing youth audiences in several post-Yugoslav states simultaneously. Yet - as studies of

${ }^{21}$ Pål Kolstø, 'Identifying with the Old or the New State: Nation-building vs Yugonostalgia in the Yugoslav Successor States', Nations and Nationalism xx/4 (2014), pp 760-81.

${ }^{22}$ See Catherine Baker, 'The Politics of Performance: Transnationalism and its Limits in Former Yugoslav Popular Music, 1999-2004', Ethnopolitics v/3 (2006), pp 275-93; Ana Petrov, Jugoslovenska muzika bez Jugoslavije (Belgrade, 2016). 
'Yugonostalgia' already accept - how far these manifestations of a common cultural space acknowledge, let alone celebrate, Yugoslavia as a political entity, let alone Yugoslav Communism as a distinctive socioeconomic ideology - vary widely. The wars thus fragmented, but did not destroy, the region's cultural connections.

\section{Post-Yugoslav cultural spaces with and without Yugoslavia}

The term 'Yugonostalgia' is often loosely applied to many more sociocultural connectivities than just those which directly evoke Tito and his federation. Even those, however, take many forms, from the gatherings celebrating Tito's birthday in his home town of Kumrovec, Croatia, to Tito's face in left-wing or anti-nationalist political graffiti, to the badges, $\mathrm{t}$-shirts and trinkets vendors sell tourists from their stalls. ${ }^{23}$ Some such connectivities, indeed, do not even include 'Yugo' in their names, but use apparently depoliticized names which audiences still tacitly understand to mean the region. The label 'Adria', which some entertainment television franchises have used in youth-orientated music programming, alludes both to the pleasures of summer tourism on the Adriatic (which used to be another experience of everyday Yugoslavism for inland Yugoslavs, including many Serbs ${ }^{24}$ ) and to the Adriatic region which, with its Italianate history, ancient Roman heritage and famously Mediterranean way of life, represents an opposite pole to 'the Balkans' in ex-Yugoslav 'symbolic geography. ${ }^{25}$ It can thus connote an aspirational, brand-ready transnationalism, free from the ideological struggles of the Yugoslav and immediate post-Yugoslav past. MTV capitalized on this first when it launched its 'MTV Adria' franchise for Slovenia, Croatia and BosniaHerzegovina in $2005,{ }^{26}$ and a post-Yugoslav X Factor franchise also took the 'Adria' name in 2013-15. ${ }^{27}$ This did not get a third season, though a similar show on TV Pink called Zvezde Granda (Stars of Grand - with contestants competing for a record deal with the pop-folk label Grand) which has run since 2004, is also shown on BiH's Open Broadcasting Network (OBN), and attracts competitors from Serbia, Montenegro, Macedonia, $\mathrm{BiH}$ plus, occasionally, Croatia. ${ }^{28}$

Another alternative to 'Yugo' nomenclature was 'Balkan', which could even connect musical production (especially pop-folk) in the post-Yugoslav region and

${ }^{23}$ Mitja Velikonja, Titostalgija: a Study of Nostalgia for Josip Broz (Ljubljana, 2008). In Serbia, and the Republika Srpska entity of $\mathrm{BiH}$, Tito merchandise may even be beside equivalent merchandise for Radovan Karadžić.

24 Stef Jansen, Antinacionalizam: etnografija otpora u Zagrebu i Beogradu (Belgrade, 2005), p 229.

25 See Milica Bakić-Hayden and Robert M Hayden, 'Orientalist Variations on the Theme 'Balkans': Symbolic Geography in Recent Yugoslav Cultural Politics'(1992) 51(1) Slavic Review 1-15; Dunja Rihtman-Auguštin, 'A Croatian Controversy: Mediterranean-Danube-Balkans' (1999) xxxvi/1 Narodna umjetnost 103-19.

26 Baker, 'Politics', p 278.

27 Produced in Serbia, its first series also involved Bosnian, Macedonian and Montenegrin contestants and judges; the Croatian broadcaster RTL joined the following year.

28 'Nova zvijezda: Zagrepčanka krenula u osvajanje folk scene', Dnevnik. $h r$, 5 January 2017, Available at: https://dnevnik.hr/showbuzz/mladi_i_neizbjezni/hana-masic-nastupila-u-zvezdamagranda---462623.html (accessed 25 January 2018). 
other south-east European countries into a transnational space. The satellite channel Balkanika, founded by two Bulgarian TV entrepreneurs in 2005, was accessible to subscribers in all post-Yugoslav states (including Slovenia and Croatia) and Bulgaria, Romania, Albania and Turkey, plus markets such as Germany, Austria and Switzerland with large combined diaspora populations. ${ }^{29}$ South-east Europe's similar-sounding, yet still nationally distinguishable, pop-folk traditions have often been recognized as part of a wider 'Ottoman ecumene' of musical culture, evidence (unwelcome as it might be to nationalist cultural purists) that south-east European musical and cultural traditions do not reduce easily to hard national boundaries. ${ }^{30}$ While this was already evident to any listeners who heard music in more than one regional language, Balkanika used satellite technology to bypass state-level media markets and give this music a novel transnational infrastructure on top of the many networks which musicians and cassette/CD pirates created for themselves. The channel also began hosting the annual 'Balkan Media Awards' in 2010, with winners attending from across the space it had defined as the Balkan region.

The Balkan Music Awards, addressing a cultural region defined by a private company rather than a nation-state, depicted - the ethnomusicologist Ana Hofman argues - a 'modern', 'cosmopolitan' Balkans, where local cultural specificities could run with the global mainstream. ${ }^{31}$ Assisting this were turns in Western pop towards 'oriental' sounds and electronic dance music which now let south-east European pop producers sound global as well as local. ${ }^{32}$ The resultant 'post-national' Balkan sound would not even reveal which country a singer came from unless the listener knew their celebrity background, though the language issue remained: the 'ekavica' variant of the ex-SerboCroatian languages was symbolically marked as Serbian (though it was also spoken in eastern Bosnia) and would be treated as such in Croatia, though Montenegrins and Bosnians who sang in the other main variant, 'ijekavica' (also the basis of Croatian), faced no such difficulty. If 2010 's 'Balkan' popular music carried a post-national sound, the memory of coexistence it brought with it could sometimes be no memory at all: a typical example from 2013, 'Hotel Jugoslavija' by the Serbian pop-folk singer Saša Kapor (a 2008-09 Zvezde Granda finalist), uses the name of the former country and the just-reopened Belgrade hotel almost in passing, telling the story of a romantic encounter with a European female tourist (who might be called Maria, Elena or Marina and come from Paris, London or Rome) asking him for directions on Slavija Square.

Kapor and his songwriters, indeed, were far from alone among young people in no longer automatically reproducing the hotel (a landmark of the socialist redevelopment of New Belgrade) as a site of Yugoslav memory by the mid-2010s. The anthropologist Ana Petrov, interviewing a 26-year-old woman in 2014 at a Dalmatian- and Mediterranean-themed club beside the Hotel Jugoslavija which often booked

29 Ana Hofman, 'Balkanske glasbe industrije med evropeizacijo in regionalizacijo: Balkanske glasbene nagrade’ (2014) 50(1) Muzikološki zbornik 157-74 at 162.

30 See Donna A. Buchanan, Balkan Popular Culture and the Ottoman Ecumene: Music, Image, and Regional Political Discourse (Lanham, MD, 2007); Rory Archer, 'Assessing Turbofolk Controversies: Popular Music between the Nation and the Balkans' (2012) xxxvi/1 Southeastern Europe 178-207.

31 Hofman, 'Balkanske glasbe industrije' 171.

32 Ibid, p 171. 
Dalmatian (ie, Croatian) singers to perform, was surprised the woman did not understand why Petrov, only six years older, was intrigued by 'a new clubbing space opening in front of some old hotel that just happened to be there. ${ }^{33}$ Petrov's observations of the atmosphere at the concert she was attending (a performance by Petar Grašo, a Dalmatian romantic ballad singer who debuted in the late 1990 s, so did not belong to the pre-war common musical past) complicates the idea that sociocultural connectedness between former Yugoslav states is automatically nostalgic. In fact, neither this Dalmatian club in Belgrade, nor the wider industry, offer Dalmatian popular music to young people in Belgrade as if it should have nostalgic value, nor as music which would have been culturally closer in their parents' youth: it does not come with the invitation to actively remember, as part of the 'affective atmosphere' of watching and hearing a singer, which did surround musicians' first contested 'return performances. ${ }^{\prime 3}$ Instead, the audience in their teens and twenties:

were unfamiliar with the symbolic value of the place where the garden was located, and even with the existence of Dalmatian music as such. They seemed reluctant to acknowledge any connections between this music and contested historical events. Instead, they claimed and behaved not only as if nothing (bad) had happened in the past, but also as if the music they were listening to that evening did not signify anything beyond itself. In other words, this event, even though connected with the sea and with Dalmatia, represents an example of the new post-Yugoslav atmosphere that rejects any potential connections with either socialist Yugoslavia or with the wars that broke up the country. ${ }^{35}$

This is far from a setting where we could assume that expressions and manifestations of sociocultural connectedness between post-Yugoslav states were nostalgic: if anything, they might discourage remembering the past. And this forgetting is, in many ways, convenient: if the young woman Petrov met was twenty-six in 2014 and had lived in Belgrade all her life, she would have been eleven when the old Hotel Jugoslavija was destroyed by the NATO bombing of Serbia and Montenegro in May 1999 during the Kosovo War; alternatively, she, or her friends, might have fled to Belgrade from Croatia or Bosnia-Herzegovina during the wars of 1991/2-95, or from Kosovo in 1999 after Milošević agreed to NATO's demands; and she would have lived much of her life amid an atmosphere of societal forgetting over Serb forces' and leaders' accountability for war crimes. Remembering the material and symbolic history of the Hotel Jugoslavija is not conducive to most people's idea of a good night out. The 'Yugosphere', examples such as Kapor's 'Hotel Jugoslavija' might suggest, is not a sphere of Yugoslav memory

\footnotetext{
33 Ana Petrov, “My Beautiful Dalmatian Song”: (Re)connecting Serbia and Dalmatia at Concerts of Dalmatian Performers in Belgrade' (2015) 4(1-2) TheMA: Open Access Research Journal for Theatre, Music, Arts. Available at: www.thema-journal.eu/index.php/thema/article/view/38/90 (accessed 6 November 2017).

${ }^{34}$ Ibid, $\mathrm{p} 11$.

35 Ibid, pp 16-17.
} 
but, increasingly, a space without one. ${ }^{36}$ It is thus more than just an inevitability of time, perhaps, which helps to explain why many instances of everyday sociocultural connectivity between post-Yugoslav states seem less apparently political. The entertainment industry often exploits these connectivities without trying to evoke the emotions of remembering Yugoslavia at all.

\section{IV 'Return performances': from nostalgia to routine}

Another phenomenon, which once seemed self-evidently nostalgic, the 'return performances' of musicians performing across a politicized boundary for the first time since Yugoslavia collapsed, has also become less so over time. Musicians and (more mobile) fans travelled between republics everyday in Yugoslavia, but this became more difficult during the collapse and then were cut off where front lines intervened. ${ }^{37}$ After the wars, these border-crossings met frequent interference from governments fearing they would undermine ethnicized nation-building projects. By the late 2000s, some routes had withered because of their audiences' weakened purchasing power, but other routes had become almost as routine as they once were. For the musicians' part, many actions, songs and performances which the media would have politicized as transgressing boundaries of national cultural identity in the early 2000s were far less likely to be framed as scandalous in the 2010s. Most Croatian musicians who had once publicly vowed never to perform in Serbia or Montenegro, stating that it would disrespect Croat war victims' memory if they went to entertain an audience from the 'aggressor' nation, had quietly set this aside by the 2010s. Lepa Brena, the pop-folk star who had personified Yugoslavia and Yugoslavism as a celebrity in the 1980s, received protests and death threats from Zagreb and Sarajevo veterans' groups on her first comeback tour in 2009, but returned to both cities with diminishing levels of abuse. Brena herself largely avoided contentious expressions of nostalgia during the tour, only singing her famous hit 'Jugoslovenka' ('Yugoslav woman') in Sarajevo once the crowd had requested it for ten minutes, and not performing 'Jugoslovenka' (or her two breakthrough hits, which mentioned Šumadija and Čačak in southern Serbia) in Zagreb at all. ${ }^{38}$

For Brena and other returning singers, the first return was always the most emotional, with more routine and smaller-scale performances likely to follow (in

36 And yet, at least some internet users still have strong enough identifications with 'Yugoslav' identity to complain songs and videos like these are not Yugoslav enough: Ana Petrov (2017) 'Yugonostalgia in the Aarket: Popular Music and Consumerism in post-Yugoslav Space' (2017) 53(1) Muzikološki zbornik $203-15$ at 208-9.

37 See Ljubica Spaskovska, 'Stairway to Hell: The Yugoslav Rock Scene and Youth during the Crisis Decade of 1981-1991' (2011) 38(2) East Central Europe 355-72. A well-known Croatian rock song from the war's first winter, 'E, moj druže beogradski' ('Oh, my friend from Belgrade') by Jura Stublić (frontman of the Zagreb 'new wave' band Film), turned this reality into a song about Stublić, imagining fighting on the front line and having to shoot back at a Serb friend who had travelled between Zagreb and Belgrade with him all the time.

38 Ana Hofman, 'Lepa Brena: Repolitization of Musical Memories on Yugoslavia' (2012) 61(1) Glasnik Etnografskog instituta SANU 21-32 at 25. 
October 2017, for instance, Brena was booked to sing at the Diamond Palace Casino in Zagreb to launch a new model of Volkswagen - hardly a controversy-courting or even spectacular event ${ }^{39}$ ). The pattern was similar with a well-publicized Croatian 'return' to Serbia, that of Tereza Kesovija, whose home town of Konavle near Dubrovnik had been ransacked by Montenegrin troops during the JNA siege of Dubrovnik which began in October 1991. Kesovija's wartime music and interviews had symbolized feminine grief by calling on Dubrovnik's patron saint (in songs dedicated to the city) and Tuđman (in her interviews) to help the city and win the war. ${ }^{40}$ In January 2011, Kesovija performed in Belgrade for the first time since the break-up of Yugoslavia.

While Serbian tabloids responded in the familiar pattern of inviting other celebrities and political or cultural figures to comment on the insult to national memory (since Kesovija, by refusing to perform in Serbia for so long, had been constructed by the same tabloids as a figure symbolising hatred towards Serbs), everyday public reactions were closer to a collective 'love and nostalgia' for Kesovija as well as Yugoslavia, and her visit and performance created a sentimental atmosphere where the past could be retold without having to dwell on the division and violence which had brought about this cultural separation. ${ }^{41} \mathrm{Her}$ future performances in Belgrade were less politically charged and more relaxed, though still charged with sentiment, this being the trademark of her stardom anyway. Reactions to Kesovija returning to Serbia were far from the vilification which Doris Dragović, another Dalmatian singer who had had a demonstratively patriotic (and in this case patriotically maternal) persona in the 1990s, had received after agreeing to perform in Igalo, Montenegro for New Year's Eve 1999..$^{42}$ The organized way in which Hajduk Split's fan club performatively rejected Dragović a few months later when she next sang to them at Hajduk's stadium left other Croatian pop musicians apprehensive of receiving the same treatment. Nothing of the sort happened to Kesovija, and indeed she returned to Belgrade for further performances in the following years.

Croatian musicians also had less to lose in the 2010s from musical transgressions which threatened the intensively-patrolled symbolic boundary between Croatian and Serbian culture, 'Europe' and the 'Balkans', Habsburg/Venetian heritage and Ottoman heritage, 'West' and 'East'. It had not helped Dragović retain her credentials of patriotic loyalty that her albums in 1999 and 2000 were both prime examples of the adaptation of Serbian pop-folk trends into Croatian zabavna (light-entertainment) music

39 'Lepa Brena ponovo stiže u Zagreb: idući petak sprema se spektakularni koncert velike regionalne zvijezde u Diamond Palace Casinu!', Jutarnji list, 29 September 2017. Available at: www.jutarnji.hr/ spektakli/strane-zvijezde/lepa-brena-ponovno-stize-u-zagreb-iduci-petak-sprema-se-

spektakularni-koncert-velike-regionalne-zvijezde-u-diamond-palace-casinu/6599172/ (accessed 9 November 2017). The showbusiness section of Jutarnji list's website still, however, filed this story under 'foreign' stars.

40 One or two Croatian stars with similar profiles to Kesovija, such as Oliver Dragojević from Split and Mišo Kovač from Šibenik, have still not performed in Serbia since the war - but it is refusal rather than travel that seems more newsworthy.

${ }^{41}$ Ana Petrov, 'The Songs we Love to Sing and the History We Like to Remember: Tereza Kesovija's Comeback in Serbia' (2015) 39(2) Southeastern Europe 192-214 at 201.

42 Amid rumours that the concert had been paid for by the Montenegrin president Milo Đukanović or members of the Montenegrin criminal elite, whereas Dragović stated it had been organized by a local Catholic priest. 
arrangements which had been popularized (though not invented) by her composer and manager Tonči Huljić, with critics likening several songs very closely to recent hits by Serbia’s most notorious pop-folk singer, Ceca Ražnatović. ${ }^{43}$ In 2006, Severina Vučković had made Croatian headlines for several weeks after winning the right to represent Croatia at the Eurovision Song Contest with a suspiciously 'Balkan'-sounding song, but in the long run the scandal enabled her to promote herself as a pan-regional star. An explicitly 'Balkan' song by a more minor Croatian singer in this ambiguous zone between zabavna music and pop-folk, Maja Šuput, released in 2015, had a contrasting fate. Šuput's 'Hej, Balkano' performed the old Yugoslav lyrical device of listing place-names from 'Vardar' to the Adriatic (one end of the (former) country to another), wrapped up in a package of musical and visual clichés from 'Balkan' film, ${ }^{44}$ but the release seemed not to generate any scandal at all - even though it took one transgressive step past Severina's song by directly incorporating Serbia itself into the collective it was addressing (one line mentioned the Belgrade landmark of Kalemegdan).

Much like Lepa Brena's early songs (and many pop-folk numbers since), 'Hej Balkano' nodded to the glamour and romance of European and global metropoles (now including Dubai), but offered 'the Balkans' (identical with the space of former Yugoslavia) as the place where her song's character, her imagined male love-interest, and her listeners could be authentically themselves ('nemoj da se lažemo kad balkanski to radimo' ${ }^{45}$ ). Its expression of what Alexander Kiossev has termed a 'Balkan popular (counter) culture', rejecting high-cultural aspirations to Western modernity, was nothing new at all for south-east Europe, but unusually unambiguous for Croatia. ${ }^{46}$ Even accounting for its self-mockery about Croatian uptightness towards the Balkans - Šuput's different outfits in the video suggest a city girl whipped up by brass-band music going wild in the mountain hut's Balkan atmosphere ${ }^{47}$ - such a performance would have been impossible in the 1990s Croatian entertainment industry, and deeply professionally risky in the 2000s. Neither was there what would once have been the predictable outcry in 2016 when Vesna Pisarović, a pop singer from the early 2000s who had represented Croatia at Eurovision in 2002 then retrained in jazz and moved to Berlin, released a jazz album with the bilingual title of Naša velika pjesmarica: The Great Yugoslav Songbook (Our Great Songbook: The Great Yugoslav Songbook). Croatian media discourse by 2015 could hardly have been described as markedly less nationalistic in a year when the 20th anniversary of victory in the Homeland War was looming (indeed, the tone of the anniversary commemorations made clear how much the 1990s

${ }^{43}$ Ceca married the paramilitary commander Željko Ražnatović-Arkan in 1995.

44 See Dina Iordanova, 'Balkan Film Representations since 1989: The Quest for Admissibility' (1998) 18(2) Historical Journal of Film, Radio and Television 263-80.

45 'Let's not lie to ourselves when we do it Balkan-style.'

46 Alexander Kiossev, 'The Dark Intimacy: Maps, Identities, Acts of Identifications', in Dušan I Bjelić and Obrad Savić (eds), Balkan as Metaphor: Between Globalization and Fragmentation (Cambridge, MA, 2002), 184

47 In fact, the semi-alpine effect of the video's winter snow might suggest it was also aimed at Slovenia, where Šuput is popular and where the mountain hut is a common video locale in Slovenia's own pop-folk, 'turbo-polka'. The song also appeared less than a year after the Polish 2014 Eurovision entry 'Mi Słowanie (We Are Slavic)', which had hypersexualized Polish village customs to create an effect not unlike Severina's in 2006. 
hegemonic public narrative about Croatian participation in the war still structured the Croatian public sphere ${ }^{48}$ ): but the likelihood of a furore over Croatian female pop stars 'flirting with the Balkans' was not what it had been.

The knowledge that pop-folk itself had openly sought to shed the associations with the Milošević regime which critics, rockers and liberals projected on to Serbian 'turbofolk' also helps to explain why 'Balkan'-tinged popular music became less controversial in Croatia. The 2000s' new Serbian stars had not been politically exposed as celebrities under Milošević; moreover, strategically minded turbo-folk entrepreneurs (including some of the genre's most famous stars like Lepa Brena and Dragana Mirković, who both owned record labels and in Mirkovićs case a satellite pop-folk music video channel, founded in December 2005) might have recognized that strong associations between pop-folk and Serbian nationalism would have limited the music's appeal to non-Serbs. ${ }^{49}$ Marko Dumančič and Krešimir Krolo have argued, therefore, that the region's contemporary pop-folk musicians largely 'brand themselves as Balkan performers, selfconsciously emphasizing a general Balkan, rather than an ethno-specific, orientation': ${ }^{50}$ most of its stars, in creating what Petrov termed 'affective atmospheres' around themselves, are not tapping their audiences' identification with ethnonational collectives.

Dumančič and Krolo's observation helps explain why young people in Croatia who enjoy dancing to recorded or live 'narodnjaci' in nightclubs do not consider their nights out (where many songs they hear will be by younger or older singers from Serbia, Montenegro and $\mathrm{BiH}$ ) to be acts of nostalgia for Yugoslavia, even though wider culture continues to problematize the question of why young Croats like to listen to turbo-folk. ${ }^{51}$ This might be an 'unintentional' revival of a common Yugoslav cultural space, ${ }^{52}$ yet if it is a force for cultural integration, it is disconnected from any political entity. If music can cross exYugoslav borders without playing on nostalgia at all, then, is nostalgia no longer a necessary or significant theme for understanding the politics of sociocultural relations in former Yugoslavia? Most musical border-crossings are certainly far less politically charged today.

\section{Beyond Yugonostalgia: nostalgia for the Yugoslav wars in popular culture}

As an interpretation of post-Yugoslav cultural continuities, Yugonostalgia may have had its day. The sociologist Dalibor Mišina, for one, has recently argued that

48 Jović, Rat $i$ mit.

${ }_{49}$ Though would not have stopped it appealing to them altogether, if Zala Volčič and Karmen Erjavec's interviews with young (non-Serb) women from Slovenia and Croatia who listened to Ceca are anything to go by - the women were aware of Ceca's associations with Serbian nationalism, but put more stock in identifying with her as the kind of successful female entrepreneur they might aspire to be: Zala Volčič and Karmen Erjavec, 'The Paradox of Ceca and the Turbo-folk Audience' (2010) 8(2) Popular Communication 103-19.

${ }^{50}$ Marko Dumančič and Krešimir Krolo. 'Dehexing Postwar West Balkan Masculinities: The Case of Bosnia, Croatia, and Serbia, 1998 to 2015’ (2017) 20(2) Men and Masculinities 154-80 at 160 (my emphasis).

51 Aleksej Gotthardi Pavlovsky, Narodnjaci i turbofolk u Hrvatskoj: zašto ih (ne) volimo? (Zagreb, 2014).

52 Dumančič and Krolo, 'Dehexing', 160. 
post-Yugoslav cultural studies must go 'beyond nostalgia', or at least 'free itself from the 'nostalgia presumption': the frame of nostalgia is not sufficient for understanding cultural production about the Yugoslav past, let alone cultural production with the sole time-frame of the post-Yugoslav present. ${ }^{53}$ The 'Yugonostalgia' paradigm, which has often been applied to apparent continuities in popular music and other cultural production between the mid-1990s and the mid-2000s, may have become part of received wisdom about post-Yugoslav cultural politics, but has far less purchase if music and musicians cannot be said to be engaging listeners, viewers and fans in processes of active remembering (contrast the more direct remembering in which bands who play songs from their own home region involve their diasporic audiences from the same places). ${ }^{54}$ Audiences are instead largely offered a cultural space which is transnational, in relation to where state borders lie, and which takes coherence from a mutually-intelligible set of language variants, cultural references, and regional-national place-myths (Vardar and the Adriatic are intelligible as external boundaries; Montenegro is a place young people aspire to go for a beach holiday; Croatian women supposedly have an active sexual appetite once they have shed their bourgeois morality and Catholic qualms) without communicating or even requiring any historical or political sense of how this space came about. It could almost be detached from the knowledge that, during or just before the early childhoods of today's young people, the country where their parents lived broke up through war.

Yet this is not the only nostalgia at work in post-Yugoslav popular culture and media. Ethnicized and mononational forms of nostalgia, which harden rather than weaken ethnopolitical divisions, also reverberate through the region's cultural politics, remediating historical memory in ways which observers had already started witnessing before Yugoslavia collapsed. ${ }^{55}$ Each country's ethnonational past, as reconstructed through older and more recent acts of myth-making, contains its own golden ages and troubled times which intellectuals, politicians and the public can translate into myths for making sense of contemporary politics, the conditions the nation faces today, and the character and intentions of groups which constitute known 'others' to the national 'self'. One aspect of such historical memory is a nostalgia for an imagined, distant and more glorious national past (the rulers, kingdoms and battles remembered in this form existed, although the details have often been heavily mythologized; 'imagined' is how much sentiment and glory the mass of the population likely felt). Some of these are long-established: for example the veneration and reappropriation of Byzantine tradition in Serbian visual art and 'etno' music (neo-traditional music packaged for a cosmopolitan 'world music' market which values authenticity and research, not for the pop-folk circuit), which connects past and present across a bridge which bypasses the many traces of Ottoman heritage in contemporary Serbian culture. ${ }^{56}$ Others are newer, such

${ }^{53}$ Mišina, 'Beyond nostalgia', 332.

54 See Hariz Halilović, Places of Pain: Forced Displacement, Popular Memory and Trans-Local Identities in Bosnian War-Torn Communities (New York, 2013), 211.

55 See Jasna Dragović-Soso, Saviours of the Nation: Serbia's Intellectual Opposition and the Revival of Nationalism (London, 2002).

${ }^{56}$ Ivan Čolović, Etno: priče o muzici sveta na Internetu (Belgrade, 2006). In 2004, Serbia’s Željko Joksimović came second at Eurovision with a repackaging of precisely this aesthetic. To the Croatian press's invented surprise, viewers in Croatia awarded him a maximum twelve points. 
as the ethnocentric narrative of today's Macedonian nation as a symbolic continuation of Alexander the Great's empire (minimising any Albanian past within Macedonian national history) which Nikola Gruevski's government made to pervade the built environment of Skopje through a grandiose programme of monument-building and 'antiquitization.57

Because a greater length of time has now passed since the break-up of Yugoslavia and the wars, however, the earlier post-Yugoslav past is now available as a focus of monoethnic nostalgia as well. The most culturally and politically significant nostalgia in today's Croatia - in the sense of political communication and cultural production which actively calls on audiences to remember the past and feel the emotions of longing for something which that past represented but today's reality ostensibly does not - is not Yugoslavia but the Homeland War of 1991-95, which Tuđman and the 1990s Croatian state (including its media), plus intellectual allies, effectively turned into a new myth of national origin rooted in living memory. By upholding this narrative in the 2000s and 2010s, the Croatian right wing - both the party Tuđman founded (the Croatian Democratic Union (HDZ)) and further-right parties which openly celebrate the symbols and military of the NDH - reproduces the myth of the Homeland War as expressing a spirit of sacrifice and unity to which the nation needs to return. This, too, is nostalgia, and a far more politicized form.

The aesthetics of Homeland War nostalgia in contemporary Croatia, indeed, create a two-way flow between politics and cultural domains including music and sport: the same communicative codes permeate the platforms of HDZ and other right-wing politicians, patriotic popular music, and national sporting culture. An indicative example, in 2013, occurred when the controversial musician and war veteran Marko Perković Thompson released a video for the song he had written as the anthem of the Croatian men's football team's supporters club. ${ }^{58}$ The lyrics and video of 'Uvijek vjerni tebi' ('Always faithful to you') linked playing or cheering for the national team with fighting for Vukovar and remembering the history of the Zrinskis and Frankopans, combining recent and historic examples of military heroism. ${ }^{59}$ The video used not only archive footage of famous goals and victories by the post-Yugoslav Croatian football

57 Andrew Graan, 'Counterfeiting the Nation: Skopje 2014 and the Politics of Nation-branding in Macedonia' (2013) 28(1) Cultural Anthropology 161-79.

58 Thompson became a professional musician in 1992 after recording a hit song about the volunteer platoon he had joined to defend his home village, and has continuously associated himself with the veterans' movement since 1998. ('Thompson' was his front-line nickname because he carried a Thompson machine-gun.) The fact that his debut song begins with the NDH's salute ' $\mathrm{Za}$ dom, spremni' ('for the Home, ready') makes every performance of this canonical and much-memorialized wartime song (unless the iconic first line is dropped) reiterate the notion that the NDH can be separated from the crimes of fascism, and arguably normalizes the slogan and the memory of the $\mathrm{NDH}$ in Croatian society: Dario Brentin, 'Ready for the Homeland?: ritual, remembrance, and political extremism in Croatian football' (2016) 44(6) Nationalities Papers 860-76 at 864. For the left, the utterance 'Za dom, spremni' is equivalent to declaring sympathy for fascism; for the revanchist right, its status as a slogan with pre-NDH noble and historic origins (as an amalgamation of two earlier Croatian battle-cries) is a patriotic truth.

59 Vukovar was besieged, then brutally captured, by the JNA and Serb paramilitaries in autumn 1991; Zrinski and Frankopan were the two greatest Croatian noble families, who produced several generations of Croatian and Habsburg military heroes in warfare against the Ottoman Empire, until the head of the two families were executed in 1691 for rebelling against Habsburg rule. 
team, but eventually also added wartime news footage of Croatian artillery pieces firing and Croatian soldiers victoriously entering Knin in August 1995, which elided sporting and military heroism just as Croatian media had done during the war. Indeed, the end of the first verse, 'kada čuješ himnu, bori se za Vukovar' ('when you hear the anthem, fight for Vukovar'), was both an encouragement to the players and an invitation for listeners to syncretically remember, layering sport and war memory together.

Although the Homeland War was a turbulent period during which thousands of Croats died and many more were forced to flee their homes, its hegemonic depictions in contemporary Croatia can nevertheless be called nostalgic. They hark back to a time of imagined dignity for the military and for Croatian tradition which the political, cultural and religious right argues has been violated by the post-Communist left, i.e. the heirs of a Yugoslav Communist regime which they charge had always been inimical to Croatian tradition and self-determination. Indeed, this frame was already emerging in the late 1990s: the first song through which Thompson associated himself with the veterans' movement, 'Prijatelji' ('Friends') in 1998, called on the fellow veterans he addressed to 'remember the proud days' ('sjetite se na ponosne dane') when they had stood beside each other, been able to do everything they wanted, and been who they had wanted to be. The lyrics presented a post-war society that had fallen short of these imagined expectations, and the video linked these sentiments to a political matter which had dismayed veterans and the right (the Hague Tribunal's prosecution of the Croat Defence Council (HVO) colonel Tihomir Blaškić for war crimes against Bosniaks in $\mathrm{BiH})$.

The promise of returning to a time of imagined dignity for the Homeland War and its veterans - the dignity which the war supposedly had under Tudman - is thus held out by today's HDZ politicians as a solution to Croatia's ongoing socioeconomic woes since the global financial crisis of 2007-08. (They have conveniently forgotten that the late 1990s veterans' movement first mobilized for greater benefits and privileges against HDZ, which was still in power.) Kolinda Grabar-Kitarovićs presidential victory speech in January 2015, as HDZ's winning candidate, looked back to the Homeland War and Tuđman's time in power as an inspiration for national regeneration. The nostalgic references simultaneously positioned her within this national grand narrative as a symbolic daughter to the father-of-the-nation figure which Tuđman had cultivated during the $1990 \mathrm{~s}^{60}$ - someone who would fulfil what Tuđman had not been able to complete because of his death in 1999. This has included a programme of rearmament and of marketing Croatia to its NATO allies as a modern, high-quality supplier of arms, equipment and military training-grounds.

Indicative of the contemporary mode of Croatian nostalgia for the Homeland War is how another of Thompson's patriotic/nationalist songs, 'Lijepa li si' ('How beautiful you are') - a song praising the nation's different regions, which he recorded with other male singers from those areas for a video released before the parliamentary elections in January 2000 - was incorporated in the mid-2010s first into the official repertoire of the Croatian Football Association (HNS) for play before important matches, then into

${ }^{60}$ See Reana Senjković, Lica društva, likovi države (Zagreb, 2002). 
military commemoration. (In 2017, Grabar-Kitarović and the HDZ prime minister Andrej Plenković were among dignitaries waving flags and singing along with it during the official commemoration of Armed Forces Day.) The reason why the HNS has been reported to international governing bodies for playing this song, and why the Armed Forces Day video caused adverse comment on social media in $\mathrm{BiH}$, is the same: that among the Croatian regions joined together by the couplets of 'Lijepa li si' is 'HercegBosna, the name of the ethnically homogenous para-state which the HVO and the Bosnian branch of HDZ had sought to create during the Bosnian conflict, with Tuđman's knowledge and support. Bosnian social media users who do not support Bosnian Croat politicians' demands to revise the Dayton constitution and create a third, Croat-identified constitutional entity (which could more easily separate and join Croatia) might well - and not unreasonably - have inferred that the president and prime minister shared Thompson's nostalgic gaze towards Herceg-Bosna. Croatia may be where ethnicized nostalgia is currently most embedded into politics: but all postYugoslav nationalisms and public cultures contain the ingredients to mobilize nostalgia in a similar way. The ethnic nation and its war experience is therefore now as important a focus for nostalgia as Yugoslavia.

\section{Conclusion}

Do we still need nostalgia to understand sociocultural relations in the Yugoslav region, and the continuities which they often appear to reveal? Nostalgia for the many things people may long for when they express 'Yugo'-nostalgia, and the ethnocentric nostalgia of phenomena such as Croatian remediation of the Homeland War (or the Republika Srpska government's contributions to the building of 'Andrićgrad', Emir Kusturica's eco-village and film set near Višegrad, one of the towns in eastern Bosnia worst affected by Serb soldiers' and paramilitaries' massacres of Bosniaks in 1992) are coexistent in today's Yugoslav region. One form of nostalgia does not exclude the other: they are both being produced at once, and ethno-nationalist nostalgia for the war years is just as significant as nostalgia for the Yugoslav period in the region's popular culture today.

Assessing the legacy of Yugoslavia, this volume argues, requires weighing up how far the successor states' post-Yugoslav elites did indeed manage to disengage their individual presents and futures from their shared Yugoslav past through the new national and political projects and narratives they created. In popular music, as in any other domain, one would therefore have to question whether there have indeed been new, non-Yugoslav beginnings in the region, and if so in what ways. Not even Slovenia and Croatia, the states where cultural policy sought most insistently to detach popular music from Yugoslav spheres of reference, have disentangled themselves in the terms that some music professionals' public statements in the early 1990s prophesied. Indeed, since popular music relies on a dialectic between the new and the familiar in order to interface with listeners' personal memories and move their emotions, it would be impossible for legacies of Yugoslavia not to have persisted, absent the kind of root-andbranch assault on evidence of everyday coexistence which even in Croatia did not fully reconfigure public consciousness. Paradoxically, though, practices of affectively 
harnessing memory, tradition and sentiments of territorial belonging which were once institutionalized into Yugoslav popular music have readily been translated into music that celebrates the ethnopolitical nation. These musical directions too are partly a legacy of Yugoslavia even when, as in Croatia, they overtly perform being orientated against a Yugoslav past.

\section{References}

Archer, Rory. 'Assessing Turbofolk Controversies: Popular Music between the Nation and the Balkans' (2012) 36(2) Southeastern Europe 178-207.

Baker, Catherine. 'The Politics of Performance: Transnationalism and its Limits in Former Yugoslav Popular Music, 1999-2004' (2006) 5(3) Ethnopolitics 275-93.

Bakić-Hayden, Milica, and Robert M Hayden. 'Orientalist Variations on the Theme 'Balkans': Symbolic Geography in Recent Yugoslav Cultural Politics' (1992) 51(1) Slavic Review 1-15.

Bellamy, Alex J. The Formation of Croatian National Identity: a Centuries-Old Dream? (Manchester, 2003).

Boym, Svetlana. The Future of Nostalgia (New York, 2001).

Brentin, Dario. 'Ready for the Homeland?: Ritual, Remembrance, and Political Extremism in Croatian Football' (2016) 44(6) Nationalities Papers 860-76.

Brubaker, Rogers. Nationalism Reframed: Nationhood and the National Question in the New Europe (Cambridge, 1996).

Buchanan, Donna A, (ed) Balkan Popular Culture and the Ottoman Ecumene: Music, Image, and Regional Political Discourse (Lanham, MD, 2007).

Čolović, Ivan. Etno: priče o muzici sveta na Internetu (Belgrade, 2006).

Dnevnik.hr. 'Nova zvijezda: Zagrepčanka krenula u osvajanje folk scene', 5 January 2017. Available at: https://dnevnik.hr/showbuzz/mladi_i_neizbjezni/hana-masic-nastupilau-zvezdama-granda---462623.html (accessed 25 January 2018).

Dragović-Soso, Jasna. Saviours of the Nation: Serbia's Intellectual Opposition and the Revival of Nationalism (London, 2002).

Dumančič, Marko, and Krešimir Krolo. 'Dehexing Postwar West Balkan Masculinities: The Case of Bosnia, Croatia, and Serbia, 1998 to 2015' (2017) 20(2) Men and Masculinities 154-80.

Eckert, Stine. 'Fighting for Recognition: Online Abuse of Women Bloggers in Germany, Switzerland, the United Kingdom, and the United States' (2018) 20(4) New Media and Society 1282-302.

Gotthardi Pavlovsky. Aleksej, Narodnjaci i turbofolk u Hrvatskoj: zašto ih (ne) volimo? (Zagreb, 2014).

Graan, Andrew. 'Counterfeiting the Nation: Skopje 2014 and the Politics of Nationbranding in Macedonia' (2013) 28(1) Cultural Anthropology 161-79.

Halilović, Hariz. Places of Pain: Forced Displacement, Popular Memory and Trans-Local Identities in Bosnian War-Torn Communities (New York, 2013).

Hofman, Ana. 'Lepa Brena: repolitization of musical memories on Yugoslavia' (2012) 60(1) Glasnik Etnografskog instituta SANU 21-32.

Hofman, Ana. 'Balkanske glasbe industrije med evropeizacijo in regionalizacijo: Balkanske glasbene nagrade’ (2014) 50 Muzikološki zbornik 50(1) 157-74.

Hofman, Ana. Novi život partizanskih pesama (Belgrade, 2016). 
Horvat, Srećko, and Igor Štiks, (eds), Welcome to the Desert of Post-Socialism: Radical Politics after Yugoslavia (London, 2015).

Iordanova, Dina. 'Balkan Film Representations since 1989: The Quest for Admissibility' (1998) 18(2) Historical Journal of Film, Radio and Television 263-80.

Jansen, Stef. Antinacionalizam: etnografija otpora u Zagrebu i Beogradu (Belgrade, 2005).

Jelača, Dijana. 'Youth after Yugoslavia: Subcultures and Phantom Pain' (2014) 5(2) Studies in East European Cinema 139-54.

Jović, Dejan. Rat i mit: politika identiteta u suvremenoj Hrvatskoj (Zagreb, 2017).

Judah, Tim. 'Yugoslavia is Dead, Long Live the Yugosphere', LSEE Research on SouthEastern Europe Working Papers 1 (London, 2009). Available at: http://eprints.lse. ac.uk/48041/1/_Libfile_repository_Content_LSEE_Papers\%20on\%20South\%20 Eastern\%20Europe_Yugoslavia\%20is\%20Dead(author).pdf (accessed 19 August 2019).

Jutarnji list, 'Lepa Brena ponovo stiže u Zagreb: idući petak sprema se spektakularni koncert velike regionalne zvijezde u Diamond Palace Casinu!', 29 September 2017. Available at: www.jutarnji.hr/spektakli/strane-zvijezde/lepa-brena-ponovno-stize-uzagreb-iduci-petak-sprema-se-spektakularni-koncert-velike-regionalne-zvijezde-udiamond-palace-casinu/6599172/ (accessed 19 August 2019).

Kiossev, Alexander. 'The Dark Intimacy: Maps, Identities, Acts of Identifications', in Dušan I Bjelić and Obrad Savić (eds), Balkan as Metaphor: Between Globalization and Fragmentation (Cambridge, MA, 2002).

Kolstø, Pål. 'Identifying with the Old or the New State: Nation-building vs Yugonostalgia in the Yugoslav Successor States' (2014) 20(4) Nations and Nationalism 760-81.

Mišina, Dalibor, "'Spit and Sing, My Yugoslavia": New Partisans, Social Critique and Bosnian Poetics of the Patriotic' (2010) 38(2) Nationalities Papers 265-89.

Mišina, Dalibor, 'Beyond Nostalgia: 'Extrospective Introspections' of the Post-Yugoslav Memory of Socialism' (2016) 50 Canadian-American Slavic Studies 332-54.

Palmberger, Monika, How Generations Remember: Conflicting Histories and Shared Memories in Post-War Bosnia and Herzegovina (London, 2016).

Perica, Vjekoslav, and Mitja Velikonja, Nebeska Jugoslavija: interakcije političkih mitologija $i$ pop-kulture (Belgrade, 2012).

Petrov, Ana, “"My Beautiful Dalmatian Song”: (Re)connecting Serbia and Dalmatia at Concerts of Dalmatian performers in Belgrade' (2015) 4(1-2) TheMA: Open Access Research Journal for Theatre, Music, Arts. Available at: www.thema-journal.eu/index. php/thema/article/view/38/90 (accessed 19 August 2019).

Petrov, Ana.'The Songs we Love to Sing and the History we like to Remember: Tereza Kesovija's comeback in Serbia' (2015) 39(2) Southeastern Europe 192-214.

Petrov, Ana. Jugoslovenska muzika bez Jugoslavije (Belgrade, 2016).

Petrov, Ana. 'Yugonostalgia in the Market: Popular Music and Consumerism in PostYugoslav Space' (2017) 53(1) Muzikološki zbornik 203-15.

Pogačar, Martin. Media Archaeologies, Micro-Archives and Storytelling: Re-Presencing the Past (London, 2016).

RFE/RL. 'Ukraine may ban Russian entrant from Eurovision over Crimea visit', 14 March 2017. Available at: www.rferl.org/a/ukraine-may-ban-russian-entrant-samoylovaeurovision-contest-over-crimea-visit/28368002.html (accessed 19 August 2019).

Rihtman-Auguštin, Dunja. 'A Croatian Controversy: Mediterranean-Danube-Balkans' (1999) 36(1) Narodna umjetnost 103-19.

Sabalić, Ines. 'Washingtonski sporazumi dramatično su izmijenili hrvatsku estradnu scenu: u Zagrebu je otvoreno petnaest lokala s novokomponiranom glazbom!', Globus, 31 March 1995. 
Senjković, Reana. Lica društva, likovi države (Zagreb, 2002).

Spaskovska, Ljubica. 'Stairway to Hell: The Yugoslav Rock Scene and Youth during the Crisis Decade of 1981-1991' (2011) 38(2) East Central Europe 355-72.

Todorova, Maria, and Zsuzsa Gille (eds), Post-Communist Nostalgia (New York, 2010).

Ugrešić, Dubravka. The Culture of Lies: Anti-Political Essays (London, 1998).

Velikonja, Mitja. "Ex-home": "Balkan Culture" in Slovenia after 1991' in Barbara

Törnquist-Plewa and Sanimir Resić (eds), The Balkans in Focus: Cultural Boundaries in Europe (Lund, 2002).

Velikonja, Mitja. Titostalgija: A Study of Nostalgia for Josip Broz (Ljubljanainstitute, 2008).

Volčič, Zala. 'Yugo-nostalgia: Cultural Memory and Media in the former Yugoslavia' (2007)

24(1) Critical Studies in Media Communication 21-38.

Volčič, Zala, and Karmen Erjavec. 'The Paradox of Ceca and the Turbo-folk Audience' (2010) 8(2) Popular Communication 103-19.

Vujačić, Veljko. Nationalism, Myth and the State in Russia and Serbia: Russian and East European Government Politics and Policy (Cambridge, 2015).

Zorn, Jelka. 'A Case for Slovene Nationalism: Initial Citizenship Rules and the Erasure' (2009) 15(2) Nations and Nationalism 280-98. 